\title{
Ascospore release by Venturia inaequalis during periods of extended daylight and low temperature at Nordic latitudes
}

\author{
Arne Stensvand • Håvard Eikemo • \\ Robert C. Seem • David M. Gadoury
}

Received: 19 December 2008/Accepted: 5 March 2009/Published online: 19 March 2009

(C) KNPV 2009

\begin{abstract}
Darkness suppresses ascospore release in Venturia inaequalis, but the impact of light levels during the extended twilight and dusk that typify Nordic spring conditions is poorly understood. Volumetric spore traps were operated at two different locations in Norway over several years. During the season of asocspore release (approximately 1 April to 30 June), on 25 occasions when rain started during night (after 23:00 $\mathrm{h}$ and before 04:00 $\mathrm{h}$ ) and leaves remained wet until at least midnight the following day, the cumulative percentage of spores trapped at sunrise did not exceed $1 \%$, irrespective of temperature. Three hours after sunrise, cumulative ascospore release reached $0.8 \%, 3.0 \%$, and $8.1 \%$ at temperatures of 0 to $5^{\circ} \mathrm{C}, 5$ to $10^{\circ} \mathrm{C}$, and $>10^{\circ} \mathrm{C}$, respectively, and $50 \%$ release occurred at 11,9 , and $8 \mathrm{~h}$ after sunrise. Additional field and laboratory studies indicated that the protracted dawn and dusk of Nordic latitudes, either alone or in combination with low temperatures,
\end{abstract}

A. Stensvand $\cdot$ H. Eikemo

Norwegian Institute for Agricultural and Environmental

Research, Plant Health and Plant Protection Division,

Høgskoleveien 7,

N-1432 Ås, Norway

R. C. Seem • D. M. Gadoury $(\bowtie)$

Department of Plant Pathology and Plant-Microbe Biology,

New York State Agricultural Experiment Station,

Cornell University,

Geneva, NY 14456, USA

e-mail: dmg4@cornell.edu does not substantially alter previously reported patterns of ascospore release.

Keywords Apple scab · Epidemiology · Aerobiology · Ascospore discharge $\cdot$ Diurnal periodicity

Ascospores of the apple scab pathogen (Venturia inaequalis) are released during spring rains from pseudothecia within overwintered leaf litter (MacHardy 1996). A diurnal pattern of release and suppression of ascospore release by darkness has been reported by several authors (Baumeister 1954; Brook 1966, 1969; Frey and Keitt 1925; Gadoury et al. 1998; Hirst et al. 1955; Hirst and Stedman 1962; Keitt and Jones 1926, MacHardy and Gadoury 1986; Pinto de Torre et al. 1984; Warner and Braun 1992). Both light intensity and quality affect the rate of ascospore release (Brook 1969; Darpoux et al. 1975; Gadoury et al. 1998; Palm 1988).

The apple growing regions of Nordic countries are at the northern limit of commercial fruit production. Apples are grown commercially in Norway at 58-62 northern latitude. Because of longer daylight periods, and protracted dawn and dusk, the light conditions during spring and summer are quantitatively different from those of more temperate regions. In Norway, emergence of the first green tissue of apple fruit buds in April is coincident with initial ascospore maturity. Bloom of apple occurs from mid to late May. Depending on the distribution of rain, the peak in release can occur from the tight cluster stage to just after petal fall 
(Brook 1976; Gadoury and MacHardy 1982; Szkolnik 1974). Thus, the season for ascospore release in $V$. inaequalis in Norway typically lasts from early to mid April to mid June (Stensvand et al. 1994, 2005). In spring, sunrise in the fruit growing regions of southern Norway occurs from 05:55 $\mathrm{h} \pm 10 \mathrm{~min}$ (April 1) to 03:20 $\mathrm{h} \pm 20 \mathrm{~min}$ (June 1), while sunset occurs from 19:10 $\mathrm{h} \pm 10 \mathrm{~min}$ (April 1) to $21: 45 \mathrm{~h} \pm 15 \mathrm{~min}$ (June 1) in the same period (Institute of Theoretical Astrophysics, Univ. of Oslo).

Early in the ascospore release season of $V$. inaequalis, low temperatures often occur during rain in Norway. It is known that the rate of ascospore release by $V$. inaequalis is suppressed at temperatures $<10^{\circ} \mathrm{C}$ (Hirst and Stedman 1962; MacHardy and Gadoury 1986; Stensvand et al. 1997), and that the reduction is greatest when temperatures approach freezing (Gadoury et al. 1996; Hirst and Stedman 1962; Stensvand et al. 1997). MacHardy and Gadoury (1986) observed that the time required to reach $90 \%$ ascospore release during a rain event was delayed by $2.5 \mathrm{~h}$ when temperatures during rain events were $<10^{\circ} \mathrm{C}$ compared to rain events $>10^{\circ} \mathrm{C}$. Temperatures $>10^{\circ} \mathrm{C}$ are not thought to affect the rate of ascospore release (Gadoury et al. 1996; MacHardy and Gadoury 1986; Seem et al. 1979).

The objective of this work was to study the combined effect of light and low temperatures under Norwegian orchard conditions in relation to previously reported diurnal and temperature-affected fluctuations in ascospore release in $V$. inaequalis. Preliminary reports from this investigation have been published elsewhere (Stensvand et al. 1994, 2000).

Burkard 7-day recording volumetric spore traps (Burkard Manufacturing Co Ltd., Rickmansworth, Hertfordshire, UK) were installed in different apple growing regions of Norway during the ascospore release seasons of 1989 to 2005. Data were obtained from Ås (south eastern Norway) during 1992 to 2004 and Hjelmeland (south western Norway) during 1992 and 1994. The spore traps were operated using either a 12-volt DC (Ås) or a 220 volt AC (Hjelmeland) power source. The traps were adjusted to sample air at $101 \mathrm{~min}^{-1}$. Two to three $\mathrm{m}^{2}$ of the orchard floor under the traps were covered with heavily infected apple leaves collected in the autumn and kept in place with a plastic screen at the trap site. A plastic tape (Melinex) attached to the clock cylinder of the spore trap served as the trapping surface. The tape was prepared, removed, dissected, and examined microscopically as described by Gadoury et al. (1996). The number of ascospores of $V$. inaequalis recorded in each transect of the microscope tape was adjusted for the proportion of the tape examined and the volume of air sampled, and are reported as spores $\mathrm{m}^{-3}$ air $\mathrm{h}^{-1}$.

Hourly records of precipitation, temperature, relative humidity, and leaf wetness were logged by onsite instruments (model KMS-P, Anton Paar KG, Graz, Austria) or weather stations (ITAS, Ås, Norway). Each device had two leaf wetness sensors, one placed outside the tree canopy at $1.5 \mathrm{~m}$ height, the other within the canopy 0.5 to $1 \mathrm{~m}$ from the canopy margin, also at $1.5 \mathrm{~m}$ height. Rain gauges recorded precipitation in increments of $0.2 \mathrm{~mm}$. Global radiation was measured by an Eppley pyranometer (Eppley Laboratory Inc., Newport, Rhode Island, USA) at the meteorological station at As approximately $1 \mathrm{~km}$ from the research orchard. Light intensity at $720 \mathrm{~nm}$, the wavelength shown in previous studies to stimulate ascospore release in $V$. inaequalis (Brook 1969; Gadoury et al. 1998) was recorded at the meteorological station and at arbitrary locations beneath trees in the adjacent orchard by a portable multispectral radiometer (model LI-1800, LI-COR Inc., Lincoln, Nebraska, USA). The daily duration of civil twilight, i.e., the duration of civil dawn plus civil dusk, was computed for Oslo, Norway and Portsmouth, New Hampshire, USA; both near sites of previous studies of diurnal periodicity of ascospore release (MacHardy and Gadoury 1986; Stensvand et al. 1994). Morning civil twilight extends from when the geometric centre of the sun is $6^{\circ}$ below the horizon until sunrise. Evening civil twilight extends from sunset until the geometric centre of the Sun is $6^{\circ}$ below the horizon.

Probit transformation (Finney 1947) was used to linearise the sigmoid cumulative distributions of daily ascospore release. These cumulative distributions were grouped for analysis similar to previous studies (Gadoury et al. 1998; MacHardy and Gadoury 1986; Stensvand et al. 1994). In the present study, the interval of 23:00 $\mathrm{h}$ to $04: 00 \mathrm{~h}$ was considered as 'night'. For episodes of $>24 \mathrm{~h}$ with leaf wetness and rain starting during night, but after midnight, spores were also accumulated from midnight to midnight the following day. If rain started prior to midnight, the consecutive day's trappings were accumulated as separate distributions lasting from midnight to mid- 
night of each day. When rain started during night and lasted $<24 \mathrm{~h}$, but $>15: 00 \mathrm{~h}$ the following afternoon, spores were accumulated from the time release started during night until 15:00 h. To ascertain an effect of light just prior to sunset on ascospore release, we separately analysed four episodes where rain and leaf wetness started within 1-2 $\mathrm{h}$ after sunset and lasted until the following afternoon (only data until 17:00 h were included). Additionally, we used a previously described laboratory apparatus (Gadoury et al. 1996) to simulate sunset and twilight conditions at Nordic latitudes and thereby investigate the effects of diminishing light upon ascospore release under controlled conditions. Dry leaf samples bearing pseudothecia were placed in the apparatus and light intensity was decreased stepwise over a $2 \mathrm{~h}$ period at $15 \mathrm{~min}$ intervals from $10.7 \mathrm{Wcm}^{-2}$ at $720 \mathrm{~nm}$ to 8 , $6,3,2,1,0.5,0.25$ and finally $0 \mathrm{Wcm}^{-2}$ at $720 \mathrm{~nm}$. Leaf samples were then subjected to simulated rain (Gadoury et al. 1996) for $2 \mathrm{~h}$ in the dark, beginning either 0,2 or $4 \mathrm{~h}$ after complete darkness was reached. As in previous studies (Gadoury et al. 1996; Stensvand et al. 1997), the dark period was immediately followed by $2 \mathrm{~h}$ of light $\left(10.7 \mu \mathrm{Wcm}^{-2}\right.$ at $720 \mathrm{~nm}$ ) to stimulate spore release, determine the total potential release of each leaf sample, and allow complete harvest and enumeration of ascospores from the leaf samples.

The duration of civil twilight was approximately $30 \%$ longer at Oslo than at Portsmouth (Fig. 1) on climate day 32 (April 1). The duration of civil twilight remained relatively constant during the ascospore release season (MacHardy and Gadoury 1986) at Portsmouth, but increased exponentially at Oslo as the summer solstice was approached (Fig. 1). On climate day 113 (June 20), the duration of civil twilight at Oslo was nearly three times that of Portsmouth (Fig. 1).

The total seasonal number of spores captured ranged from 3,511 to 92,108 . On 26 occasions, rain started during night and leaves remained wet until at least midnight the following day. These episodes were subdivided into three groups based upon the mean temperature of the period of leaf wetness; (i) $0-5^{\circ} \mathrm{C}$ (9 episodes); (ii) $5-10^{\circ} \mathrm{C}$ (13 episodes); and (iii) $>10^{\circ} \mathrm{C}$ (4 episodes). At sunrise, the mean cumulative percentages (standard deviation in parenthesis) of spores trapped for the three temperature ranges were $0.16(0.29), 0.85(2.2)$ and 0.99 (1.50),

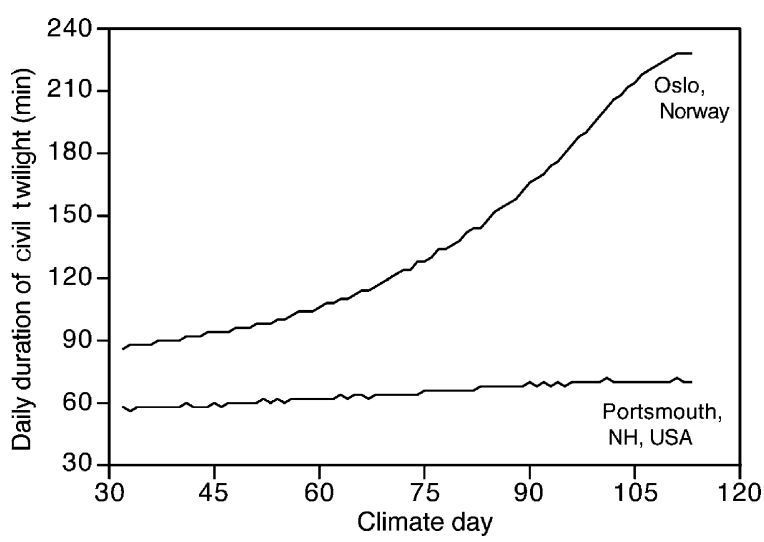

Fig. 1 Duration of civil twilight (morning civil twilight plus evening civil twilight) at Oslo, Norway and Portsmouth, New Hampshire, USA. Morning civil twilight extends from when the geometric centre of the sun is $6^{\circ}$ below the horizon until sunrise. Evening civil twilight extends from sunset until the geometric centre of the sun is $6^{\circ}$ below the horizon. Climate day is the number of days after 1 March

respectively. The mean percentages (standard deviation in parenthesis) of cumulative spore trapping $3 \mathrm{~h}$ after sunrise was 0.84 (1.14), 3.05 (5.10) and 8.1 (3.38) for the same temperature ranges, respectively. Linear regression of the probit of the cumulative percentage of ascospores trapped (Y) between 5 to $10^{\circ} \mathrm{C}$ against hours after sunrise $(\mathrm{X})$ yielded the equation $\mathrm{Y}=-2.87+0.308 \mathrm{X}$, with an $\mathrm{R}^{2}$ of 0.93 , $\mathrm{SE}=0.0051$ and a $90 \%$ prediction interval $(\mathrm{PI})$ of $\mathrm{Y} \pm 0.88$. A linear regression for probits $<5^{\circ} \mathrm{C}$ yielded the equation $\mathrm{Y}=-3.08+0.315 \mathrm{X}, \mathrm{R}^{2}=0.85, \mathrm{SE}=$ 0.0122 , and $90 \%$ PI of $\mathrm{Y} \pm 1.1$. The model was retransformed to percentages and is shown in comparison to a model developed from probit-transformed cumulative percentages of ascospore release $>10^{\circ} \mathrm{C}$ in Fig. 2 ( $\mathrm{Y}=-2.35+0.307 \mathrm{X}, \mathrm{R}^{2}=0.91, \mathrm{SE}=0.0120$, $\mathrm{PI}=\mathrm{Y} \pm 0.98)$. The models predicted delays in reaching $50 \%$ release at $7.3,9.3$, and $9.8 \mathrm{~h}$ after sunrise at $>10^{\circ} \mathrm{C}, 5-10^{\circ} \mathrm{C}$, and $0-5^{\circ} \mathrm{C}$, respectively, (Fig. 2). On seven occasions $<10^{\circ} \mathrm{C}$ (range 1.2 to $9.1^{\circ} \mathrm{C}$ ), rain and leaf wetness started during night (after 23:00 $\mathrm{h}$ and before 04:00 h) and continued throughout the next morning and day, but leaves remained wet for $<24 \mathrm{~h}$ (Fig. 2). The pattern of ascospore release was similar to that observed when leaf wetness continued for $24 \mathrm{~h}$, with a clear night time suppression of spore release (Fig. 3).

In the four episodes where rain started within $1-2 \mathrm{~h}$ after sunset, $1.15,2.4,2.6$ and $25.0 \%$ of the total 


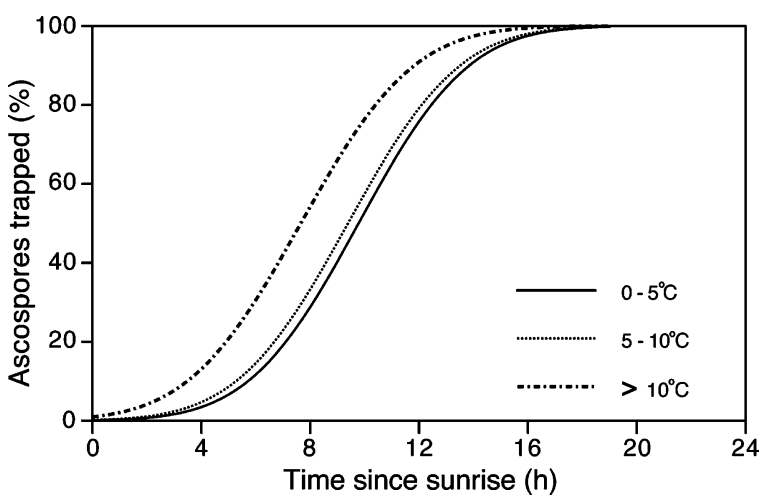

Fig. 2 Three models of cumulative ascospore release by $V$. inaequalis at 0 to $5^{\circ} \mathrm{C}, 5$ to $10^{\circ} \mathrm{C}$, and $>10^{\circ} \mathrm{C}$. Events were selected in which rain and leaf wetness started at night (between 23:00 $\mathrm{h}$ and 04:00 h) and continued to the following midnight (or beyond). Cumulative percentages of ascospores trapped in each release event were probit transformed and analysed by linear regression

ascospores trapped during the release event were released prior to sunrise. In the lattermost episode, $23 \%$ of the $25 \%$ of spores released after sunset were released prior to midnight. In the wind tunnel apparatus, there was a rapid and small increase in ascospore release during the first minutes after the rain started in darkness (Fig. 4), and 13.0, 7.1, and 10.6 of the spores were released during the first $2 \mathrm{~h}$ after start of rain in the dark if rain started 0,2 or $4 \mathrm{~h}$, respectively, after start of complete darkness (Fig. 4). After the initial spore release in the dark, few spores were released until the leaf sample was illuminated. Light intensity in the wind tunnel studies ranged from those approximating values recorded at mid-day under

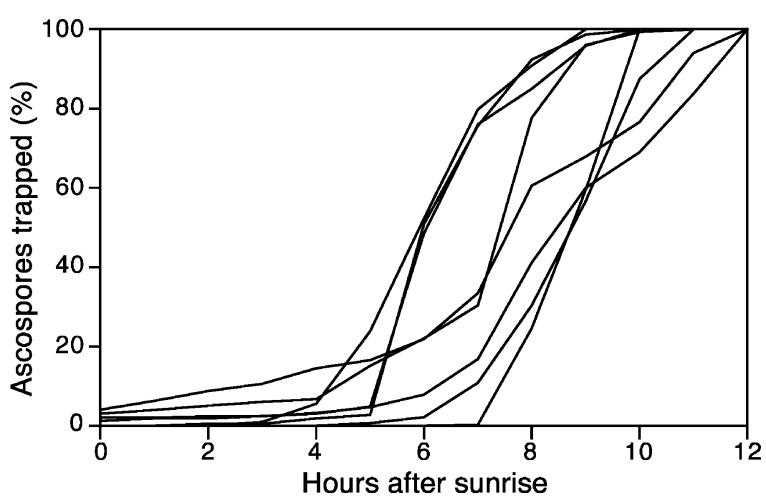

Fig. 3 Cumulative ascospore release by $V$. inaequalis during eight episodes with mean temperatures of $<10^{\circ} \mathrm{C}$; and during which rain and leaf wetness started at night (between 23:00 h and 04:00 h) and continued to the following afternoon heavy cloud cover and rain to values recorded under the same conditions just prior to sunrise or sunset.

The spectral distribution was recorded at the Ås meteorological station on 7 May 1993, which is normally the early to middle part of the primary inoculum season for $V$. inaequalis in Norway. May 7 had continuous rainfall and complete cloud cover during the night and morning. Sunrise was at 04:00 h. At $720 \mathrm{~nm}$, light intensity was $0.02 \mu \mathrm{Wcm}^{-2}$ at 04:00 h, it reached $0.63 \mu \mathrm{Wcm}^{-2}$ at 05:00 h, and varied between 0.9 and $3.8 \mu \mathrm{Wcm}^{-2}$ in succeeding measurements until noon. The global radiation was $0.17 \mathrm{Wm}^{-2}$ at $03: 30 \mathrm{~h}$, it was 0.67 and $5.9 \mathrm{Wm}^{-2}$ at 04.00 and 05:00 $\mathrm{h}$, respectively, and varied between 9.4 and $55.7 \mathrm{Wm}^{-2}$ in succeeding measurements until noon. Spectral distribution was also recorded during one evening and night June 19 in 1993, which is normally at the very end of the ascospore release season. The weather was cloudy and rainy, with a heavy cloud cover from ca. 18:00 h until after midnight. Sunset was at 21:40 h. At $720 \mathrm{~nm}$, the light intensity was $1.0 \mu \mathrm{Wcm}^{-2}$ at $21: 00 \mathrm{~h}$ and $0.27 \mu \mathrm{Wcm}^{-2}$ at $21: 30 \mathrm{~h}$. At $22: 30 \mathrm{~h}$ it was $<0.01 \mu \mathrm{Wcm}^{-2}$. When comparing measurements in the open space between tree rows in an apple orchard in close vicinity to the meteorological station, no significant difference $(P=0.05$, Student's t-test $)$ in light intensity was detected. On a cloudy day at the early bloom stage, a 20 to $50 \%$ reduction in light intensity at $720 \mathrm{~nm}$ was recorded on the ground under the canopies, compared to between the rows. A

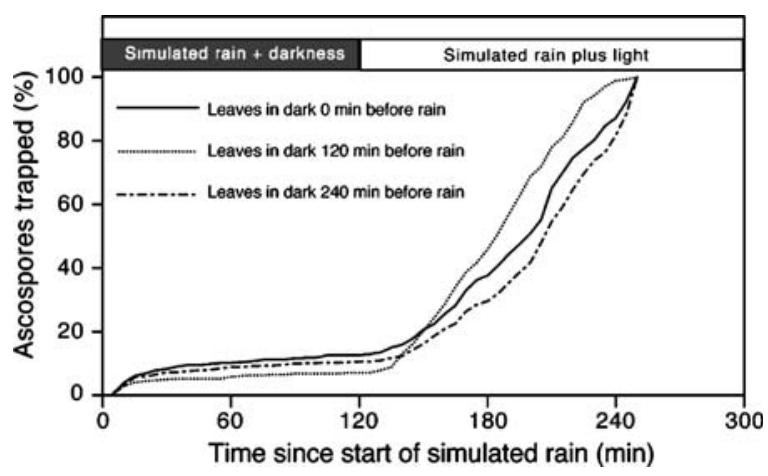

Fig. 4 Ascospore release from leaf samples in a controlledenvironment wind tunnel. Replicated samples were subjected to a simulated sunset, followed by simulated rain beginning 0,2 or $4 \mathrm{~h}$ after all light was extinguished. All samples were then illuminated $\left(10.7 \mu \mathrm{Wcm}^{-2}\right)$ for an additional $2 \mathrm{~h}$ as simulated rain continued in order to completely harvest all available ascospores 
similar measurement carried out on a cloudy day ca. 2 weeks after the primary inoculum season was over, showed a 40 to $50 \%$ reduction in light intensity under the canopies.

Despite the short night and greatly extended twilight typical of Nordic latitudes (Fig. 1), there remained a clear suppression of ascospore release during night similar to that described in New Hampshire (MacHardy and Gadoury 1986). Low temperatures further delayed the increase in spore release at dawn compared to higher temperatures, thus extending the period of suppressed release. This is in accordance with previous investigations (Hirst and Stedman 1962; MacHardy and Gadoury 1986; Stensvand et al. 1997) insofar as discharge during a specified 'night' interval, although the exact hours comprising the night interval differ at Nordic latitudes. To this, we can add that the bulk of the predicted delay in ascospore release due to low temperatures occurs between 5 and $10^{\circ} \mathrm{C}(+1.5 \mathrm{~h})$, with an additional predicted delay of only $30 \mathrm{~min}$ as temperatures fall from 5 to $0^{\circ} \mathrm{C}$ (Fig. 2).

MacHardy and Gadoury (1986) reported $>97 \%$ of the spores to be released between 07:00 and 18:00 $\mathrm{h}$ if rain began at night (before 07:00 h) and leaves remained wet for $>24 \mathrm{~h}$. In similar rain and leaf wetness periods in the present study, a mean of approximately $87 \%$ (variation from 62.5 to $99.2 \%$ ) of the spores were released between 07:00 and 18:00 h. During mid April, the day is approximately $1 \mathrm{~h}$ longer in the fruit growing areas in Norway compared to New Hampshire. By mid May the time difference is 2.5 to $3 \mathrm{~h}$ and by mid June it is 4 to $5 \mathrm{~h}$. Thus, at Nordic latitudes it is not advisable to use fixed times for an entire season to denote the hours of suppressed ascospore release. For example, we recorded high quantities of spores between 18:00 and 21:00 h, and sometimes even later, due to longer daylight periods. However, as in previous studies, when rain and leaf wetness started after sunset and lasted until the next afternoon, very small spore quantities were trapped in the late evening and night. The wind tunnel experiments confirmed that only a small proportion of the spores will be discharged when rain starts in darkness, even when rain begins immediately after the start of the dark period.

Palm (1988) indicated that few ascospores of the apple scab fungus are released at light levels below 2000 lux. In natural daylight, 2000 lux equals approximately $8 \mu \mathrm{Wcm}^{-2}$ global radiation. On a rainy day in early May a global radiation at this level was reached between 05:00 and 05:30 h, which is approximately $1-1 \frac{1}{2} \mathrm{~h}$ after sunrise. Gadoury et al. (1998) in New York, found the light level we recorded at $05: 00 \mathrm{~h}(1 \mathrm{~h}$ after sunrise $)$ on a rainy day $\left(0.63 \mu \mathrm{Wcm}^{-2}\right)$ sufficient to stimulate spore release in $V$. inaequalis in the laboratory. The same light levels were also reached within $1 \mathrm{~h}$ prior to sunset on a rainy day in the current study. According to our light measurements there was some reduction in the light level under the tree canopies, but approximately $30 \mathrm{~min}$ after the stimulatory level was reached in the open, it was also reached under the tree canopy. From records of ascospore trapping and light measurements it can be concluded that the light intensity prior to sunrise or after sunset had no or very little stimulatory effect on ascospore release in $V$. inaequalis. In summary, we found no evidence that protracted dawn and dusk at Nordic latitudes increased the rate of spore release. Light levels occurring $1 \mathrm{~h}$ after sunrise are the minimum required to stimulate spore release in morning. Conversely, light levels occurring within $1 \mathrm{~h}$ prior to sunset suppress ascospore release.

Suppression of spore release during morning hours was very pronounced at low temperatures. As in previous laboratory (Hirst and Stedman 1962; Stensvand et al. 2000) and field studies (Hirst and Stedman 1962; MacHardy and Gadoury 1986), temperatures $<10^{\circ} \mathrm{C}$ during morning hours delayed the stimulation of spore release by 2 to $3 \mathrm{~h}$ despite the quantitative differences in the rate at which light intensity increases at Nordic latitudes. Models fitted to data on cumulative ascospore release at 0 to $5^{\circ} \mathrm{C}$ or 5 to $10^{\circ} \mathrm{C}$ predicted that ascospore release would remain $<3 \%$ for $3 \mathrm{~h}$ after sunrise.

The practical implications of suppressed spore release during night and at low temperatures have been discussed at length by previous authors (MacHardy and Gadoury 1986; Palm 1988; Stensvand et al. 2000), particularly with respect to considerations of absolute inoculum dose, e.g., Potential Ascospore Dose, or PAD sensu MacHardy (1996). To this, we can add that extended dawn and dusk at Nordic latitudes do not substantially modify the interactions between light, temperature, and ascospore release, and thus management recommendations based upon this relationship and proven 
elsewhere (MacHardy 1996) could be likewise applied within the Nordic apple growing regions.

\section{References}

Baumeister, G. (1954). Weitere Untersuchungen zur Biologie des Apfelschorfes. Mitteilungen aus der Biologischen Bundesanstalt für Land und Forstwirtschaft (BerlinDahlem), 80, 98-102.

Brook, P. J. (1966). The ascospore production season of Venturia inaequalis (Cke.) Wint., the apple black spot fungus. New Zealand Journal of Agricultural Research, 9, 1064-1069.

Brook, P. J. (1969). Effects of light, temperature, and moisture on release of ascospores by Venturia inaequalis (Cke.) Wint. New Zealand Journal of Agricultural Research, 12, 214-227.

Brook, P. J. (1976). Seasonal pattern of maturation of Venturia inaequalis ascospores in New Zealand. New Zealand Journal of Agricultural Research, 19, 103-109.

Darpoux, H., Lebrun, A., \& de la Tullaye, B. (1975). Action de traitements sur la formation des perithecec et la production de l'inoculum primaire de Venturia inaequalis (Cooke) Wint. et de Venturia pirina Aderh. Phytiatrie-Phytopharmacie, 24, 3-14.

Finney, D. J. (1947). Probit analysis. A statistical treatment of the sigmoid response curve, pp 256. Cambridge University Press.

Frey, C. N., \& Keitt, G. W. (1925). Studies of spore dissemination of Venturia inaequalis (Cke.) Wint. in relation to seasonal development of apple scab. Journal of Agricultural Research, 15, 529-540.

Gadoury, D. M., \& MacHardy, W. E. (1982). A model to estimate the maturity of ascospores of Venturia inaequalis. Phytopathology, 72, 901-904. doi:10.1094/Phyto-72-901.

Gadoury, D. M., Stensvand, A., \& Seem, R. C. (1996). A wind tunnel for controlled-environment studies of ascospore release by Venturia inaequalis. Phytopathology, 86, 596601. doi:10.1094/Phyto-86-596.

Gadoury, D. M., Stensvand, A., \& Seem, R. C. (1998). Influence of light, relative humidity, and maturity of populations on discharge of ascospores of Venturia inaequalis. Phytopathology, 88, 902-909. doi:10.1094/ PHYTO.1998.88.9.902.

Hirst, J. M., Storey, I. F., Ward, W. C., \& Wilcox, H. J. (1955). The origin of apple scab epidemics in the Wisbech area in 1953 and 1954. Plant Pathology, 4, 91-96. doi:10.1111/ j.1365-3059.1955.tb00749.x.
Hirst, J. M., \& Stedman, O. J. (1962). The epidemiology of apple scab (Venturia inaequalis (Cke.) Wint.) II. Observations on the liberation of ascospores. The Annals of Applied Biology, 50, 525-550. doi:10.1111/j.1744-7348.1962.tb06047.x.

Keitt, G. W., \& Jones, L. K. (1926). Studies of the epidemiology and control of apple scab. Wisconsin Agricultural Experiment Station Research Bulletin, 73, 104.

MacHardy, W. E. (1996). Apple scab biology, epidemiology, and management, $545 \mathrm{pp}$. APS Press.

MacHardy, W. E., \& Gadoury, D. M. (1986). Patterns of ascospore discharge by Venturia inaequalis. Phytopathology, 76, 985-990. doi:10.1094/Phyto-76-985.

Palm, G. (1988). Untersuchungen über den Einfluß der Belichtungsstärke für den Askosporenausstoß des Schorfpilzes (Venturia inaequalis, Venturia pirina). Mitteilungen aus der Biologischen Bundesanstalt für Land- und Forstwirtschaft (Berlin-Dahlem), 245, 420.

Pinto de Torre, A., Carreño, I. I., \& Moller, W. (1984). Control quimico de Venturia en manzanos. Applicaciones a calendario fijo o cuando el tiempo favorece la infeccion Niveles de inoculo primario. Agricultura Tecnica (Chile), 44, 123-130.

Seem, R. C., Gilpatrick, J. D., \& Szkolnik, M. (1979). Quantitative effects of microclimate on spore development and dispersal systems of apple scab, pp 135-137. In: Proceedings of Symposia IX International Congress of Plant Protection, Washington D.C. 5-11 August.

Stensvand, A., Amundsen, T., \& Semb, L. (1994). Apple scab (Venturia inaequalis) - patterns of ascospore release in Norway. Norwegian Journal of Agricultural Sciences, 17, 49-54.

Stensvand, A., Eikemo, H., Gadoury, D. M., \& Seem, R. C. (2005). Use of a rainfall frequency threshold to adjust a degree day model of ascospore maturity of Venturia inaequalis. Plant Disease, 89, 198-202. doi:10.1094/PD89-0198.

Stensvand, A., Gadoury, D. M., Amundsen, T., \& Seem, R. C. (2000). Recent research on ascospore discharge in Venturia inaequalis. IOBC/WPRS Bulletin, 23(12), 39-51.

Stensvand, A., Gadoury, D. M., Amundsen, T., Semb, L., \& Seem, R. C. (1997). Ascospore release and infection of apple leaves by conidia and ascospores of Venturia inaequalis at low temperatures. Phytopathology, 87, 1046-1053. doi:10.1094/PHYTO.1997.87.10.1046.

Szkolnik, M. (1974). Apple scab ascospore release as related to apple fruit bud development and calendar dates. Proceedings of The American Phytopathological Society, 1, 146.

Warner, J., \& Braun, P. G. (1992). Discharge of Venturia inaequalis ascospores during daytime and nighttime wetting periods in Ontario and Nova Scotia. Canadian Journal of Plant Pathology, 14, 315-321. 